KAZIMIERZ MISIASZEK

\title{
SALEZJANIE W POSZUKIWANIU ODPOWIEDZI NA WSPÓŁCZESNE WYZWANIA W POLSCE
}

Streszczenie: Salezjanie, którzy obchodzą w tym roku 20o-lecie urodzin swojego założyciela, św. Jana Bosko, wezwani są do odpowiedzi na współczesne wyzwania w dziedzinie wychowania. Muszą poszukiwać ich w dzisiejszym społeczeństwie, które jest nacechowane chaosem w dziedzinie wartości, liberalnym podejściem do tradycji, kultury i religii. Salezjanie w tej sytuacji mają zmierzać zarówno do zapewnienia wychowankowi poczucia stabilności i egzystencjalnego bezpieczeństwa, jak i do wychowania człowieka. Innym obszarem poszukiwania odpowiedzi jest rodzina. Salezjanie mają pamiętać, że pierwszymi wychowawcami są rodzice, wspólnie z nimi, nie sami, muszą zabiegać o integralne wychowanie młodego pokolenia. Mają wychowywać przez miłość do miłości, zgodnie z systemem prewencyjnym. Dzisiejsi rodzice potrzebują w swoich zadaniach wychowawczych wsparcia. Może nim być katecheza rodziny czy katecheza dorosłych. Dlatego salezjanie powinni bardziej otwierać się na wychowywanie ludzi dorosłych. Ich szczególnym zadaniem jest też troska o rozwój oratorium jako paradygmatu wychowania w stylu prewencyjnym.

Słowa kluczowe: św. Jan Bosko, wyzwania wychowawcze, rodzina, katecheza rodziny, katecheza dorosłych, oratorium

\section{Wprowadzenie}

Charakter systemu prewencyjnego św. Jana Bosko w sposób wystarczający motywuje salezjanów do poszukiwania odpowiedzi na współczesne wyzwania w Polsce. Jego podstawowe rozumienie jako zapobiegania czy uprzedzania zawiera w sobie wyraźny rodzaj pedagogicznego przewidywania takiego rozwoju wychowania, aby już dziś programować jego przyszłe linie czy kierunki. Wyzwania wychowawcze są obecne we współczesnym życiu społecznym, kulturowym, politycznym i eklezjalnym. Stanowią podstawę działań wychowawczych, które gwarantują takie możliwości przystosowania systemu prewencyjnego, aby zapewnić integralny rozwój wychowanka. Doświadczenie historii pozwala na postawienie tego rodzaju tezy. Wychowanie zaproponowane przez św. Jana Bosko okazało się bowiem 
zdolne do tego, co zostało określone podczas Soboru Watykańskiego II terminem aggiornamento, a więc przystosowania się do określonych warunków społecznych i kulturowych. Zastanówmy się więc, gdzie należałoby poszukiwać wyzwań dla salezjanów i Rodziny Salezjańskiej dzisiaj w Polsce i jak na nie odpowiedzieć.

\section{Poszukiwanie odpowiedzi w aktualnym kontekście społeczno-kulturowym}

Życie społeczne, jak również kultura, podlegają dzisiaj w Polsce radykalnym przemianom. W postępującym procesie globalizacji, obok wartości, istnieje też ryzyko wyrażające się w tym, jak wskazuje Benedykt XVI, „że faktycznej wzajemnej zależności między ludźmi i narodami nie odpowiada etyczne współdziałanie sumień i umysłów, którego wynikiem mógłby być rozwój naprawdę ludzki” (Benedykt XVI 2009, nr 9). Realność tego ryzyka potwierdzają fakty. Jesteśmy bowiem świadkami podejmowania w Polsce, czy to ze strony rządowej i administracyjnej, czy to ze strony różnych ośrodków lewicowych i liberalnych, działań zmierzających nie tylko do zakłócenia, ale i uniemożliwienia podejmowania czynności czy dokonywania rozstrzygnięć na podstawie sumienia i prawdy. Tymczasem, jak znów przypomina Benedykt XVI, „bez prawdy człowiek skazuje się na empiryczną i sceptyczną wizję życia, niezdolną wznieść się ponad praxis, ponieważ nie interesuje jej dostrzeżenie wartości - a czasem nawet znaczeń - dzięki którym mogłaby ją osądzać i ukierunkowywać. Wierność człowiekowi wymaga wierności prawdzie, która jako jedyna gwarantuje wolność (por. J 8, 32) i możliwość integralnego rozwoju ludzkiego" (Benedykt XVI 2009, nr 9).

Należy być też świadomym, że wraz z epoką postmodernistyczną, ponowoczesną, a także wraz z demokratyzowaniem się świata pojawiły się w życiu społecznym, politycznym i w kulturze liberalne prądy z wyraźną dominacją kwestii ekonomicznych pretendujących do niemalże naczelnego wyznacznika ludzkich zainteresowań. W chwili obecnej liberalizm nie jest tylko doktryną obowiązującą w gospodarce i ekonomii, ale stał się sposobem przeżywania życia. Dotyczy myślenia, wyborów, ocen i wartościowania, także w sferze moralnej, w sferze wartości. Jego wyrazem jest nadmierny indywidualizm, subiektywizm, relatywizm. W efekcie współczesność została poddana roszczeniom tegoż indywidualizmu, dodatkowo ukierunkowanego rywalizacyjnie, czego przykładem są chociażby wciąż ponawiane publicznie apele o kreatywność, przedsiębiorczość, konkurencyjność, co w praktyce jednak oznacza brak promocji zasady solidarnej pomocy, dopuszczenie zniszczenia konkurenta, który przestał być wspólnikiem interesów. W obszarze szkoły dobrą ilustracją tej postawy jest tzw. uczniowski wyścig szczurów, niszczący wzajemną pomoc we wspólnym uczeniu się (Misiaszek 2014, s. 155).

Ponadto indywidualizm został wsparty subiektywizmem i relatywizmem w podejściu do życia i wartości. W tego typu postawie w centrum znajduje się nieomylne „ja”, które dystansuje się od tego, co nie wynika z bezpośredniego i doświadczalnego poznania podmiotu, uznającego za prawdę tylko swój sposób podejścia do 
rzeczywistości. Ta zasada została także zastosowana do religii, którą pragnie się zamknąć w sferze prywatnej. Głosi się również neutralność światopoglądową państwa, której przecież de facto nie ma, każdy bowiem wybór jest związany z przyjęciem czy odrzuceniem określonych wartości, a więc jest jakimś stanowiskiem światopoglądowym. Jednakże tym, co wydaje się trudnością największą, jest zagubienie epistemologii: brak kryterium prawdy i dobra w teorii poznania sprawia, że wolność przeżywa się jako samowolę i swawolę. W edukacji znajduje to wyraz w braku określonej filozofii czy teorii wychowania, w której można by znaleźć odpowiedź na pytanie, jakiego człowieka szkoła chce kształcić i wychowywać. Nie znajdziemy jednak w szkole ani takiego pytania, ani tym bardziej odpowiedzi. Tym samym generuje ona stan chaosu aksjologicznego, w którym uniemożliwia się wychowanie ucznia tak, aby można było mówić o jego pełnym i integralnym rozwoju. Nie przyczynią się z pewnością do tego rodzaju rozwoju umiejętności czy sprawności, które tak mocno podkreśla się w aktach prawnych z dziedziny edukacji (Rozporzadzenie Ministra Edukacji Narodowej... 2012). Niebudowane na określonej hierarchii wartości nie zawsze mogą wyrabiać w uczniu zdolność do rozróżniania dobra i zła, będącą podstawą nabywania umiejętności. Uczeń może, wbrew intencji prawodawcy, wyrabiać w sobie te umiejętności, które służą jego interesom, nie zawsze dobrym.

Wobec takiej sytuacji salezjanie są wezwani do tego, aby wspomagać wychowanka w nabywaniu przez niego poczucia osobowej tożsamości. W stanie chaosu aksjologicznego, nieokreśloności, rozchwiania młody człowiek potrzebuje świadectwa dojrzałych w swoich przekonaniach osób dorosłych, podobnie jak potrzebuje poczucia stabilności, egzystencjalnego bezpieczeństwa. Nie można bowiem rozwijać się i dojrzewać w sytuacji chaosu i rozchwiania. Salezjanie, jak również członkowie Rodziny Salezjańskiej, posiadają odpowiedni rodzaj narzędzi, przede wszystkim system prewencyjny św. Jana Bosko z istotnymi dla niego założeniami: rozumem, religią i miłością wychowawczą (Cian 2001; Misiaszek 2012; Weinschenk 1996), których właściwe zastosowanie może doprowadzić do pełnego i integralnego rozwoju wychowanka. Wydaje się bowiem, że dzisiaj nadszedł nowy czas pracy u podstaw, pracy organicznej, w której będzie chodziło o proponowanie wychowankowi fundamentów dla jego rozwoju, aby był właśnie integralny, to znaczy dotyczył całego człowieka. Inaczej mówiąc, jeszcze raz za Benedyktem XVI, we współzawodnictwie różnych wizji człowieka proponowanych dzisiejszemu człowiekowi istotne jest to, aby potwierdzać i uzasadniać bezwarunkową wartość osoby ludzkiej oraz sensu jej wzrastania (Benedykt XVI 2009, nr 18). Owszem, okoliczności są niesprzyjające, czego aktualnym dowodem może być ratyfikacja przez mieniącego się chrześcijaninem prezydenta RP konwencji wymierzonej wprost w kulturę, religię i rodzinę jako rzekomo generujące przemoc kobiet w rodzinie. Nie dostrzegł on tkwiących w niej wyraźnie ideologicznych treści, zapewne z powodu koniunkturalnej chęci zyskania większej liczby wyborców. Paradoksalnie jednak czasy te sprzyjają mobilizacji, wyjściu z uśpienia, bardziej świadomym działaniom, personalnej odpowiedzialności, 
jak również, a może przede wszystkim, pogłębieniu świadomości, jak ważne jest niezagubienie i nierozmywanie wartości, w tym także wartości wychowawczych obecnych w chrześcijaństwie.

\section{Poszukiwanie odpowiedzi w rodzinie wychowanka}

Salezjanie od Soboru Watykańskiego II do czasów obecnych dokonali wielkiej pracy na rzecz określenia osoby wychowanka. W wyniku obrad kapituł generalnych, inspektorialnych, refleksji nad praktyką wychowawczą dokonywaną w konkretnych wspólnotach dzisiaj jest on postrzegany w kontekście nie tylko pełnego rozwoju osobowego, ale i społecznego, kulturowego, jak również religijnego. Salezjanie zostali szczególnie uwrażliwieni na działalność wśród tej młodzieży, którą ostatnia kapituła generalna (dwudziesta siódma) określiła jako żyjącą na „peryferiach współczesnego życia”, tradycyjnie nazywamy ją ubogą i potrzebującą wielorakiej pomocy. Peryferia te zostały wskazane jako sytuacje zagrożenia, w których żyją młodzi, są to: emigracja, uchodźstwo, bezrobocie, zatrudnianie nieletnich itp. Jednocześnie salezjanie kierują do samych siebie apel, aby poznawać nowe granice życiowe i geograficzne najbiedniejszej młodzieży (XXVII Kapituła Generalna Salezjanów Księdza Bosko 2014, s. 53-54).

Nie chciałbym jednak zajmować się analizą samej biedy w odniesieniu do salezjańskiego wychowanka, gdyż dokonały jej już, i to nieraz, różne instancje salezjańskie. Moim celem jest zwrócenie uwagi na jedną z podstawowych wspólnot, która decyduje o kondycji życiowej młodego człowieka, a mianowicie rodzinę. Nie można bowiem postrzegać wychowanka bez rodziny i całego kontekstu życia rodzinnego. Ona bowiem, co jest oczywiste, pozostaje wciąż pierwszą wspólnotą wychowawczą, a wszystkie inne pełnią funkcję wspomagania dokonywanych w niej działań wychowawczych, co na przykład jest zapisane w Ustawie o systemie oświaty z 7 września 1991 roku, gdzie mówi się o szkole jako instytucji wspomagającej wychowawczą rolę rodziny (art. 1). Podobnie wypowiada się Kościół - w deklaracji o wychowaniu chrześcijańskim Gravissimum educationis twierdzi się, że rodziców należy uważać za pierwszych i najlepszych wychowawców, których powinno wspierać całe społeczeństwo (Sobór Watykański II 1965, nr 3). Wszystkie więc działania wychowawcze podejmowane w celu towarzyszenia rozwojowi młodego człowieka mają - jako punkt wyjścia i zarazem wciąż stały oraz najważniejszy punkt odniesienia - uwzględniać rodzinę. Ten rodzaj działań, który nie uwzględniałby rodziny oraz wszystkich wpływających na nią uwarunkowań, pozostanie natomiast nie tylko nieskuteczny, ale i w gruncie rzeczy nietrafny. W tej sytuacji wydaje się czymś oczywistym, że rodzina dla salezjanów jest właściwym miejscem poszukiwania odpowiedzi na współczesne wyzwania. Tym bardziej że to w niej objawia się i właściwie urzeczywistnia komunia kościelna, tworząc „Kościół domowy” (Jan Paweł II 1981, nr 21). W ten sposób rodzina jest miejscem rozumienia i odczytywania 
Bożego zamiaru względem nas, zawsze jednakże w wielowymiarowym kontekście, czy to natury psychologicznej, społecznej, politycznej, kulturowej, czy eklezjalnej.

Dla salezjanów wskazanie na Kościół jest niezmiernie istotne: są powołani w Kościele i dla Kościoła. Jest to dla nich ważne także dlatego, ponieważ w nim jest przechowywany depozyt orędzia zbawienia, w którym rodzina odnajduje swoją tożsamość, przede wszystkim - jak naucza Jan Paweł II - poprzez miłość. W adhortacji apostolskiej Familiaris consortio tak o niej nauczał: „W perspektywie sięgającej samych korzeni rzeczywistości małżeńskiej i rodzinnej trzeba [...] powiedzieć, że istota i zadania rodziny są ostatecznie określone przez miłość. Dlatego rodzina otrzymuje misję strzeżenia, objawiania i przekazywania miłości, będącej żywym odbiciem i rzeczywistym udzielaniem się miłości Bożej ludzkości oraz miłości Chrystusa Pana Kościołowi, Jego oblubienicy" (Jan Paweł II 1981, nr 17). Ta tworząca wspólnotę małżeńską i rodzinną miłość znajduje swoje dalsze pogłębienie, gdy rodzinie wyznaczane są zadania: tworzenie wspólnoty osób, służba życiu, udział w rozwoju społeczeństwa oraz uczestnictwo w życiu i posłannictwie Kościoła (Jan Paweł II 1981).

W tej samej perspektywie ujmowania miłości jako siły sprawczej komunii małżeńskiej i rodzinnej można lepiej zrozumieć wychowanie zaproponowane przez św. Jana Bosko, który właśnie w niej upatrywał fundamentalną siłę propozycji kierowanych do wychowanków. Jednoznacznie też określał charakter swojej wspólnoty wychowawczej, która miała być tworzona właśnie na wzór wspólnoty rodzinnej. Dlatego twierdził, że praktyka systemu prewencyjnego oparta jest na słowach św. Pawła: „Caritas benigna est, patiens est; omnia suffert, omnia sperat, omnia sustinet” (Bosco 1965a, s. 294). Wielokrotnie powtarzał również, że „wychowanie jest sprawą serca”, jak również był przekonany, że razem z miłością wzmacnia się autorytet wychowawcy. W miłości upatrywał wreszcie fundament relacji wychowawcy z wychowankiem: „Jeżeli chcesz, żeby cię szanowano - mówił do wychowawców - postępuj tak, aby cię najpierw pokochano" (Bosco 1965b, s. 322).

Podejmowanie kwestii dotyczących rodziny w odniesieniu do wychowania realizowanego przez salezjanów oraz członków Rodziny Salezjańskiej i ujmowanych w aspektach poszukiwania odpowiedzi na współczesne wyzwania ma swoje podwójne uzasadnienie. Z jednej strony, jest wskazaniem na trafność i aktualność propozycji wychowawczych realizowanych we wspólnocie, którą ma przenikać - jak twierdził nasz założyciel - klimat rodzinny, będący dziedzictwem salezjańskim, jego marką. Z drugiej jednak strony, pojawia się jakiś rodzaj niepokoju powodowanego niedostatecznym dostrzeganiem wagi i znaczenia rodziny dla współczesnego wychowania salezjańskiego. Uważna lektura ostatnich dokumentów salezjańskich, zarówno na płaszczyźnie kapituł generalnych, jak i prowincjalnych (inspektorialnych), a także obserwacja lokalnej praktyki mogą rodzić przekonanie, że wychowanie młodzieży staje się działalnością autonomiczną, jakby wyizolowaną z kontekstu rodzinnego. Wyprowadzane i formułowane cele oraz zadania niekoniecznie mają za punkt wyjścia, ale i dojścia, rodzinę. 
Czytając dokumenty XXVI Kapituły Generalnej, poświęcone wychowaniu i ewangelizacji młodzieży, należy stwierdzić, że istnieje jakiś rodzaj skróconej w tym zakresie perspektywy. W dokumentach tych bowiem nie dostrzega się dostatecznie związku między ewangelizacją rodziców a skutecznością pracy wychowawczej z młodzieżą, jak również potrzeby ewangelizowania samych rodziców. Jakkolwiek w dokumentach XXVII Kapituły Generalnej znalazło się stwierdzenie, że rodzina jest pierwotnym podmiotem wychowania i pierwszym miejscem ewangelizacji, to jednak we wnioskach ograniczono się jedynie do polecenia, aby duszpasterstwo młodzieży coraz bardziej otwierało się na duszpasterstwo rodzin (XXVI Kapituła Generalna Salezjanów Księdza Bosko 2008, s. 66). Treści te ponadto nie są w dokumencie integralną częścią tych stwierdzeń, które odnoszą się wprost do procesu ewangelizowania młodzieży, ale są jakby dopowiedziane. Tymczasem wydaje się, że wychowywanie i ewangelizowanie młodych nabiera nowej jakości i skuteczności wówczas, gdy wprzęgnięta jest w nie rodzina, a działania kościelne ją wspomagają. Ponadto należy być świadomym, że ewangelizowanie samych młodych jest z zasady nie do końca skuteczne, podobnie jak nieskuteczne są działania wychowawcze, w których brakuje podstawowej roli rodziców. Młodzież jest, owszem, otwarta na propozycje ewangelizacyjne Kościoła, lecz - jak obserwujemy - w zakresie zaspokajania potrzeb bycia razem i ekspresji siebie, przeżycia czegoś nowego, doświadczenia innego niż zwykle spotkania we wspólnocie parafialnej. Chodziłoby jednak o to, aby proces ewangelizowania był obecny w życiu codziennym rodziny, realnie wpływając na kształtowanie postaw i zachowań.

Prawo do formułowania określonych powyżej wyzwań wynika z faktu, że mamy do czynienia ze spadkiem udziału ludzi młodych w codziennym życiu Kościoła. Mówi się nawet o „wyjściu młodych z Kościoła”, co daje się realnie zweryfikować w praktyce duszpasterskiej, szczególnie tej, która związana jest z sakramentem bierzmowania. Nie od dziś twierdzi się, że sakrament ten nie jest wejściem coraz bardziej odpowiedzialnie w życie Kościoła, ale sakramentem wyjścia z niego. Co więcej, dzisiaj można także obserwować, że wyjście z Kościoła ma miejsce już po przyjęciu Pierwszej Komunii Świętej. W tej sytuacji istnieje pilna potrzeba związania procesu wychowania i ewangelizacji z rodziną jako podstawowym punktem wyjścia i stałym punktem odniesienia. Jest to wyzwanie, które realnie pojawia się przed salezjanami i Rodziną Salezjańską.

\section{Poszukiwanie odpowiedzi w katechezie dorosłych (katechezie rodziny)}

Opisana powyżej sytuacja rodzi inne pytanie: czy salezjanie nie powinni poszukiwać odpowiedzi na współczesne problemy wychowania i ewangelizacji, a tym samym także wyzwania, w katechezie dorosłych (Misiaszek 2002) czy też w katechezie rodziny (Stala 2010)? Kościół od samych swoich początków wychowywał dorosłych, wspomagając rodzinę w wychowywaniu potomstwa, a katechizacja młodego pokolenia w formie usystematyzowanej pojawiła się o wiele później, 
w okresie potrydenckim, rozwinęła się natomiast w XX wieku. Tę katechezę dorosłych Jan Paweł II nazwał najznakomitszą formą, podając znamienne uzasadnienie: „ponieważ zwraca się ona do osób wykonujących największe zadania i w ogóle zdolnych do życia według orędzia chrześcijańskiego i to w jego pełni. [...] Świat, w którym młodzi mają żyć i świadczyć o wierze, którą katecheza stara się zbadać i utwierdzić, po większej części znajduje się we władaniu dorosłych, dlatego też ich wiara powinna być również stale oświecana, wzmacniana i odnawiana, aby przeniknęła całą działalność doczesną, za którą są odpowiedzialni. Aby zaś katecheza mogła być skuteczna, powinna być ciągła; będzie bowiem rzeczywiście daremna, jeśli zatrzyma się na samym progu wieku dojrzałego” (Jan Paweł II 1979, nr 43).

W Kościele w Polsce formacja chrześcijańska rzeczywiście zatrzymała się na samym progu wieku dojrzałego. Z trudem możemy znaleźć takie wspólnoty chrześcijańskie, w których istnieje i rozwija się katecheza dorosłych, nie mówiąc o katechezie rodziny. Można więc pytać za Janem Pawłem II: czy rzeczywiście formacja religijna ludzi młodych nie jest przypadkiem daremna? Analiza współczesnej rzeczywistości każe odpowiedzieć, niestety, twierdząco. Wychowanie chrześcijańskie w szkole nie daje się zweryfikować w codziennych postawach religijnych ludzi młodych. Nie ma także katechezy parafialnej, która mogłaby, bardziej niż szkolne nauczanie religii, przyczynić się do pełnej i integralnej formacji chrześcijańskiej. Czy więc w tej sytuacji jakimś rozwiązaniem nie byłaby katecheza dorosłych, katecheza rodziny?

Istnieją dwie podstawowe racje uzasadniające katechezę dorosłych czy katechezę rodziny. Pierwszą jest potrzeba bardziej systematycznej i integralnej formacji chrześcijańskiej samych dorosłych, aby stawali się bardziej świadomymi i odpowiedzialnymi chrześcijanami, traktującymi swoją wiarę nie jako prywatną wartość, jak chciałyby dzisiaj różne opiniotwórcze centra i media, ale jako określoną koncepcję życia. Religia bowiem nigdy nie jest prywatną własnością, ale właśnie koncepcją życia. Inaczej mówiąc, celem katechezy dorosłych jest dojrzałość wiary czy też w wierze, prowadząca do powstawania dojrzałych wspólnot chrześcijańskich. W sytuacji Kościoła w Polsce, zmagającego się z propagowanym laickim stylem życia, indyferencją światopoglądową, chaosem w dziedzinie wartości i właśnie „prywatyzowaniem” religii, ale również z przerostem czynnika instytucjonalnego w swoich strukturach, istnieje nagląca potrzeba formowania dojrzałych chrześcijan i dojrzałych wspólnot chrześcijańskich, gwarantujących stabilny fundament dla wiary. Nie staną się nim same religijne wspólnoty młodzieżowe, gdyż wymagają obecności ludzi dojrzałych w wierze, po to właśnie, aby młodzież mogła dojrzewać.

Rodzina też wymaga dzisiaj pomocy, gdyż jest wiele przyczyn jej dysfunkcyjności, z którymi sama sobie nie poradzi. Rodzą się one w samej rodzinie, ale wynikają także z określonego (choć chciałoby się raczej powiedzieć: nieokreślonego) rodzaju polityki państwa. Znamy z pewnością z własnych doświadczeń trudności, jakich doświadcza dzisiaj rodzina, i wiemy, jak znikome jest wsparcie udzielane jej przez państwo, nie tyle w sensie bezpośredniej pomocy finansowej, ile w tworzeniu 
i respektowaniu odpowiedniego rodzaju prawa. W tym kontekście chrześcijańska formacja rodziców jest $\mathrm{z}$ pewnością także istotnym rodzajem pomocy, w której celem nie są tylko treści wiary, ale i podejmowanie problemów ludzi dorosłych, aby byli świadomi swoich praw i obowiązków.

Katecheza dorosłych w swoich założeniach pojawia się też jako szczególny, i bywa, że niezastąpiony, czynnik wsparcia procesu wychowywania młodzieży. Dojrzali w swojej wierze rodzice, świadomi swoich powinności w zakresie chrześcijańskiej formacji, skuteczniej wesprą rozwój i wychowywanie własnego potomstwa. I związki te wydają się oczywiste, niejako narzucające się wprost. Dlatego w programie wychowawczym Rodziny Salezjańskiej nie może zabraknąć chrześcijańskiej formacji ludzi dorosłych, w tym przede wszystkim rodziców. I nie będzie to sprzeczne z młodzieżowym profilem salezjanów, stanie się raczej dowodem na realne podejście do wychowywania ludzi młodych. Wychowywanie młodzieży znajdzie w ten sposób swojego naturalnego sojusznika czy też swój właściwy podmiot, którym są rodzice.

\section{Poszukiwanie odpowiedzi w salezjańskich wspólnotach wychowawczych}

W końcu należy szukać odpowiedzi na współczesne wyzwania także w salezjańskich wspólnotach wychowawczych. Wydaje się, że szczególne miejsce wśród nich zajmuje oratorium. Nie deprecjonuję w ten sposób innych wspólnot wychowawczych, które pojawiły się dzisiaj jako odpowiedź na potrzeby ludzi młodych, czyli ruchów czy grup ewangelizacyjnych. Są one niezmiernie istotne i musimy wciąż znajdować nowe formy pracy wychowawczej i ewangelizacyjnej z młodzieżą, odpowiednie do zmieniających się czasów. Podobnie jak należy nieustannie pytać, na ile szkoła salezjańska odpowiada na potrzeby współczesnego społeczeństwa. Być może należałoby więcej uwagi poświęcić szkołom zawodowym, może już nie w tradycyjnym ujęciu, ale na przykład w formie szkół politechnicznych jako bardziej przystosowanych do obecnych czasów. Są to dla nas wyzwania, które pojawiają się wręcz jako rodzaj imperatywu, zarówno na poziomie poszczególnych wspólnot lokalnych, jak i prowincjalnych, inspektorialnych.

Oratorium jednak jest szczególną formą pracy salezjańskiej, i to nie tylko z racji tradycji sięgającej czasów św. Jana Bosko. Okazuje się bowiem, że w swoich założeniach jest wciąż aktualne i potrzebne (Misiaszek 1996). Jego szczególny rys, jakim jest połączenie aspektów religijnych i kulturalnych (kulturowych), odpowiada dogłębnie założeniom wychowania chrześcijańskiego. Te dwie rzeczywistości, jakimi są wiara i kultura, tworzą bowiem podstawowe filary życia chrześcijańskiego, które znajdują swoje miejsce również w wychowaniu. Paweł VI w adhortacji Evangelii nuntiandi przestrzegał przed rozdźwiękiem między wiarą i kulturą. Niestety, rozdźwięk ten istnieje. W dzisiejszych czasach św. Jan Paweł II przypomniał ten problem, przedstawiając go w ciekawy sposób: „Wiara, która nie staje się kulturą, nie jest wiarą w pełni przyjętą, w pełni przemyślaną, przeżytą wiernie”. A przecież 
salezjanie mają narzędzie, które może pomóc zarówno niwelować istniejący rozdźwięk między wiarą i kulturą, jak i pracować na rzecz wiary stającej się kulturą.

Oratorium jest właśnie w salezjańskiej praktyce wychowawczej tą wspólnotą, czy też instytucją, w której wiara i kultura znajdują swoje miejsce, z założenia dążącą do pełnego, integralnego wychowania osoby ludzkiej. To właśnie w nim salezjanie mogą pokazać, w jaki sposób wiara staje się kulturą, aby rzeczywiście była pełna. Należałoby jednak poświęcić mu więcej uwagi i przyczynić się do jego ponownego rozkwitu. Jest bowiem zbyt cenną wartością, aby uległo pomniejszeniu. To duże wyzwanie dla salezjanów.

Rocznica urodzin św. Jana Bosko jest dla salezjanów dobrym i właściwym momentem do dokonania całościowej refleksji nad swoim posłannictwem wychowawczym w Kościele. Jest to ważne, gdyż zmieniające się dynamicznie czasy wymagają, jak zresztą w każdym rodzaju wychowania, podjęcia odpowiednich poszukiwań i dokonania przystosowań, aby udzielana wychowankowi odpowiedź była wiarygodna. Dzisiaj należy przede wszystkim nie tylko zwrócić uwagę na rodzinę, ale zwrócić się do rodziny, aby wspólnie z nią prowadzić dzieło wychowania. Inaczej nie osiągnie się pożądanego skutku. Rodzina jednak wymaga obecnie wielorakiej pomocy, gdyż jest osaczona przez wiele niebezpieczeństw, jakie rodzą się we współczesnym życiu społecznym i politycznym. Państwo nie prowadzi przekonywającej polityki rodzinnej, a czasami wydaje się, że jest bardziej zainteresowane promocją mniejszości seksualnych niż rozwojem rodziny, czego przykładem jest przyjęcie tzw. konwencji antyprzemocowej. Jakkolwiek salezjanie dotąd nie dowartościowywali wystarczająco pracy z rodziną i w rodzinie, to jednak wydaje się, że dzisiaj „rodzinna” praca wychowawcza staje się dla nich koniecznością. To w niej i poprzez nią mają poszukiwać odpowiedzi na pojawiające się problemy w dziedzinie wychowania. Dysponują odpowiednimi środkami, aby zaproponować zarówno cele, treści, jak i metody wychowania. Muszą jednak ożywić życie oratoryjne, które wydaje się dzisiaj bardzo potrzebne do wychowania nie tylko młodego człowieka, ale i dorosłych, w tym rodziców.

\section{Bibliografia}

XXVI Kapituła Generalna Salezjanów Księdza Bosko (2008). „Da mihi animas, caetera tolle". Rzym.

XXVII Kapituła Generalna Salezjanów Księdza Bosko (2014). Świadkowie ewangelicznego radykalizmu. Rzym.

Benedykt XVI (2009). Encyklika Caritas in veritate. O integralnym rozwoju ludzkim w miłości i prawdzie. Kraków: Wydawnictwo M.

Bosco G. (1965a). Il sistema preventivo nell'educazione della gioventù. W: Bosco G., Scritti sul sistema preventivo nell'educazione della gioventù, red. Braido P., Brescia: La Scuola Editrice. 
Bosco G. (1965b). Regolamento per le case della Società di S. Francesco di Sales. W: Bosco G., Scritti sul sistema preventivo nell'educazione della gioventù, red. Braido P., Brescia: La Scouola Editrice.

Cian L. (2001). System zapobiegawczy św. Jana Bosko i jego charakterystyka. Warszawa: Wydawnictwo Salezjańskie.

Deklaracja o wychowaniu chrześcijańskim Gravissimum educationis (1965).

Jan Paweł II (1979). Adhortacja apostolska Catechesi tradendae. Rzym.

Jan Paweł II (1981). Adhortacja apostolska Familiaris consortio. Rzym.

Jan Paweł II (1982). List do Kardynała Sekretarza Stanu Agostino Casaroli. W: Jan Paweł II (1986). Wiara i kultura. Dokumenty, przemówienia, homilie. Rzym: Fundacja Jana Pawła II, Polski Instytut Kultury Chrześcijańskiej.

Misiaszek K. (red.). (2002). Katecheza dorosłych we wspólnocie Kościoła. Warszawa: Wydawnictwo Salezjańskie.

Misiaszek K. (1996). Młodzież w centrum pastoralnej troski salezjanów: oratoryjna propozycja pracy z młodzieża dla Kościoła w Polsce. „Seminare”, t. 12, s. 197-211.

Misiaszek K. (2012). Pedagogia salezjanów (Towarzystwa św. Franciszka Salezego). W: Kostkiewicz J. (red.). Pedagogie katolickich zgromadzeń zakonnych. Historia i współczesność. T. 1. Kraków: Oficyna Wydawnicza „Impuls”.

Misiaszek K. (2014). Wychowanie religijne młodzieży wobec chaosu kulturowego na przykładzie szkoły. W: Sadowski R. (red.). Młodzież w przestrzeni wolności. W poszukiwaniu odpowiedzi na zmiany ustrojowe po roku 1989. Warszawa: Towarzystwo Naukowe Franciszka Salezego.

Rozporzadzenie Ministra Edukacji Narodowej z dnia 27 sierpnia 2012 r. w sprawie podstawy programowej wychowania przedszkolnego oraz kształcenia ogólnego w poszczególnych typach szkół, Dz.U. 2012, poz. 977.

Stala J. (2010). W kierunku integralnej edukacji religijnej w rodzinie (Próba refleksji nad nauczaniem Jana Pawła II w kontekście polskich uwarunkowań). Lublin: Polihymnia.

Ustawa o systemie oświaty, Dz.U. 1991, nr 95, poz. 425.

Weinschenk R. (1996). Podstawy pedagogiki Księdza Bosko. Warszawa: Wydawnictwo Salezjańskie.

\title{
THE SALESIANS IN THE SEARCH FOR ANSWERS TO MODERN CHALLENGES IN POLAND
}

\begin{abstract}
The Salesians, who celebrate this year the 2ooth anniversary of the birth of their founder, St. John Bosco, are called to respond to the contemporary challenges in the field of education. One of them is the search for answers in today's society. It is characterized by chaos in the field of values, liberal approach to tradition, culture, and religion.
\end{abstract}


In this situation, the Salesians seek to ensure pupil existential sense of stability and security. It is achieved by an educational system based on reason, religion, and love. It can assist in the education of the whole person.

Another area to search for answers is the family. The Salesians cannot forget that parents are the first educators. That is why we, as Salesians, and the parents together aim to seek the integral education of the younger generation. Emphasized by St. John Bosco, in this context love means a value indicating the direction of family education: to educate by love for love. Today, however, parents need instruction support in their work. This may mean family catechesis and catechesis of adults. Therefore the Salesians should be more open to educating adults so that parents would be more aware of their Christian duties.

The last area to finding answers to the challenges are existing educational institutions in the Salesian Congregation. The first is the oratory, somewhat today neglected by the Polish Salesians. Meanwhile, the chance of an education can be attained due to the fact that religion and culture are to be combined.

Key words: John Bosco, the challenges of education, family, family catechesis, catechesis of adults, oratorio

Kazimierz Misiaszek - profesor zwyczajny doktor habilitowany, ksiądz salezjanin, dyrektor Instytutu Teologii Praktycznej i kierownik Katedry Dydaktyki Katechetycznej w Wydziale Teologicznym Uniwersytetu Kardynała Stefana Wyszyńskiego w Warszawie. Autor m.in. następujących książek: Koncepcja nauczania religii katolickiej w publicznej szkole włoskiej po Konkordacie z 1984 roku (2009), Koncepcja nauczania religii katolickiej w publicznej szkole polskiej (2010). Adres e-mail: kazmis@op.pl. 